Volume 17 (2020)

\title{
Indeks Penulis
}

Adityarizqy Putradinantyo 37

Aktavia Herawati 56

A. Z. Purwono Budi Santoso 26, 65, 92

Didi Saidi 65

Djoko Mulyanto 45

Dyah Arbiwati 26, 37

Emma Trinurani Sofyan 56

Fahmi Herwinastwan Prakosa 1

Ganjar Herdiansyah 56

Lanjar Sudarto 37

Lelanti Peniwiratri 1

M. Kundarto 11, 37

M. Nurcholis 74, 92

Miseri Roeslan Afany 20

Muhammad Ali Ma'sum 11

Novita Andarwati 92

Partoyo 11, 74

Putri Puji Astuti 65

R Agus Widodo 1, 20

Rachmad Fajar Wibisono 26

Saedi Bawana 56

Tedi Kurnia Putra 20

Tri Mulyadi 74 


\section{PEDOMAN PENULISAN NASKAH}

Naskah yang dimuat adalah hasil penelitian atau konsep pemikiran dalam bidang ilmu tanah dan keairan yang belum pernah diterbitkan atau tidak sedang dalam penyuntingan di publikasi lainnya.

Naskah ditulis dalam bahasa Indonesia atau bahasa Inggris, diketik menggunakan pengolah kata MS Word dengan layout 1 kolom ukuran kertas kwarto dengan margin $3 \mathrm{~cm}$, spasi 1, Times New Roman 12. Jumlah halaman keseluruhan termasuk table dan ilustrasi maksimal 20 halaman termasuk gambar dan tabel, disusun sebagai berikut:

\section{Halaman Sampul}

Judul, Nama Penulis, Alamat lengkap, Instansi Penulis beserta no.telp/fax dan e-mail penulis (bila ada), tanggal pengiriman naskah.

\section{Halaman Isi}

JUDUL (maksimal 14 kata); ABSTRAK (dalam bahasa inggris dan Indonesia, 1 paragraf 1 spasi, font 11,maks. 250 kata) yang secara lengkap memaparkan tujuan, metode, hasil penelitian dan kesimpulan dengan kata kunci; secara alfabetis: (tidak lebih dari 5 istilah); PENDAHULUAN; BAHAN DAN METODE; HASIL DAN PEMBAHASAN; KESIMPULAN; DAFTAR PUSTAKA (disarankan lebih dari $80 \%$ acuan dari jurnal terbitan 10 tahun terakhir). Judul BAB ditulis di tengah, kapital, cetak tebal, tanpa nomor. Judul Sub Bab ditulis di margin kiri, kapital pada awal kata, tanpa nomor. Penulisan simbol matematik, unsur kimia, satuam metrik menggunakan Standar Sistem Internasional. Istilah asing atau nama ilmiah dicetak miring.

Contoh penulisan sumber kutipan/pengacuan di dalam naskah:

. Bailey (1993) menyatakan bahwa ....

.... sesuai dengan jenis lempung dalam batuan karbonat (White, 1988; Mulyanto,2006).

Contoh penulisan daftar pustaka:

\section{Jurnal}

Prendergast, JB. 1995. Soil Water Bypass and Solute Transport Under Irrigated Pasture. Soil Sci. Soc. Am. J. 59:1531-1539.

\section{Skripsi/Tesis/Disertasi}

Nursyamsi D. 2008. Pelepasan kalium terfiksasi dengan penambahan asam oksalat dan kation untuk meningkatkan kalium tersedia bagi tanaman pada tanah-tanah yang didominasi mineral liat smektit. [Disertasi]. Institut Pertanian Bogor, Bogor. (in Indonesian).

\section{Buku}

White, W. B. 1988. Geomorphology and Hidrology of Karst Terrains. Oxford University Press.

\section{Bab dalam buku}

Bailey, SW. 1993. Review of the Structural Relationship of the Kaolin Minerals. In: Murray H, Bundy W, Harvey C(editor). Kaolin Genesis and Utilization. Boulder, CO: The Clay Mineral Society.p 5-42.

\section{Prosiding}

Wagg, C., Bender, S. F., Widmer, F., \& Van der Heijden, M. G. A. (2014). Soil biodiversity and soil community composition determine ecosystem multifunctionality. Proceedings of the National Academy of Sciences of the United States of America, 111(14), 55-60. https://doi. org/10.1073/pnas.1320054111.

\section{Informasi dari Internet}

Foster, J., D.J. Chittleborough, and K. barovich.2006. Genesis of Terra Rossa over Marble and the Influence of a Neighbouring Texture Contrast Soil at Delamere, South Australia. http://www.regional.org.au/asssi/Foster,J/Left permission.doc. [12 Mei 2006]

\section{Tabel dan Ilustrasi}

Tabel disajikan terbuka, tanpa kolom, menggunakan program MS Word atau MS Excel. Ilustrasi dijital disarankan menggunakan format JPG, hitam putih. Ilustrasi berupa foto dicetak pada kertas mengkilap, hitam putih. 


\section{Daftar Isi}

6. Material Volkanik sebagai Penyusun Utama Tanah Merah di Atas

Batuan Karbonat Karangsari Wonosari

(Volcanic Materials as a Main Constituent of Red Soils Overlying The Carbonate Rock of Karangsari, Wonosari)

\section{Djoko Mulyanto}

7. Perkembangan Tanah dari Bahan Induk Vulkanik di Desa Cileles,

Kecamatan Jatinangor

(Development of Soil from Volcanic Parent Material in Cileles Village, Jatinangor District)

Ganjar Herdiansyah, Emma Trinurani Sofyan, Saedi Bawana dan Aktavia Herawati

8. Kualitas Tanah pada Lahan Sawah dengan Irigasi Air Rawa Jombor di Kecamatan Bayat Kabupaten Klaten

(Soil Qualitiy in Paddy Fields with Irrigation Water from Rawa Jombor in Bayat District, Klaten Regency)

Putri Puji Astuti, Didi Saidi, dan AZ. Purwono Budi Santosa

9. Beberapa Sifat Kimia Tanah Sawah atas Penggunaan Pupuk Organik dengan Kurun Waktu Berbeda di Sayegan, Sleman

(Some Chemical Properties of Paddy Soil on The Organic Fertilizer Applications with Different Periods in Seyegan, Sleman)

Tri Mulyadi, M. Nurcholis, dan Partoyo

10. Pendugaan Erosi di Lahan Kering dengan Metode USLE di Sub

Sub DAS Dengkeng Kecamatan Bulu dan Weru Kabupaten Sukoharjo Provinsi Jawa Tengah

(Soil Erosion Prediction on Dryland Using USLE Method at Dengkeng Sub-Sub Watershed in Bulu and Weru Sub District Sukoharjo District Central Java Province)

Novita Andarwati, A. Z. Purwono Budi Santoso, dan M. Nurcholis 